\title{
An Artificial Human Tooth from the Neolithic Cemetery at Gebel Ramlah, Egypt
}

\author{
Joel D. Irish", Przemyslaw Bobrowski* ${ }^{* *}$, Michal Kobusiewicz ${ }^{* *}$, Jacek Kabaciski**, and Romuald \\ Schild ${ }^{\text {knt }}$ \\ "Department of Anthropology, University of Alaska Fairbanks, Fairbanks, AK 99775 \\ *Institute of Archaeology and Ethnology, Polish Academy of Sciences, 60-814 Poznan, Poland \\ *** Institute of Archaeology and Ethnology, Polish Academy of Sciences, 00-140 Warsaw, Poland
}

ABSTRACT Excavations at the Gebel Ramlah cemetery, in Upper Egypt's Western Desert, have provided numerous data concerning mortuary practices of the local Final Neolithic period populace. Previous articles have chronicled treatment of disturbed inhumations, in which great care had been taken to recover and rebury all grave goods and skeletal elements including, most notably, dental remains. In several cases, the Neolithic

In January and February of 2003, members of the Combined Prehistoric Expedition, under the direction of Romuald Schild, Polish Academy of Sciences, continued an ongoing investigation of Neolithic archaeological sites in Upper Egypt's Western Desert. One goal of the field season was to complete the excavation of a cemetery near Gebel Ramlah, a promontory located approximately $30 \mathrm{~km}$ northwest of Nabta Playa (see Wendorf and Schild, 2001), and some $250 \mathrm{~km}$ southwest of Aswan (Fig. 1).

Previous fieldwork at the cemetery, which was originally discovered in 2000, revealed three concentrations of human skeletons and grave goods. During 2001, the easternmost concentration was excavated, and 30 sets of remains were recovered. Typological analyses of associated pottery and other artifacts originally suggested that they date to the Late Neolithic period. However, recent radiocarbon dating (Kobusiewicz et al., n.d.) places them in the first half of the fifth millennium BC, which corresponds (see Wendorf et al., 1984; Wendorf and Schild, 1999, 2001) to an early Final Neolithic assignation. Of the many finds at the cemetery, one of the more interesting entails evidence of extreme care that was given to those remains disturbed by later inhumations. Beyond collecting all of the bones and grave goods for secondary burial, the Neolithic gravediggers also made an effort to recover dental remains that had fallen from their jaws during handling. In two cases, teeth had been reinserted into the alveoli; this action was discerned because several were found to have been placed in incorrect anatomical positions (Irish et al., 2003). Additional details concerning this treatment, as well information on the positioning of remains, the grave goods, and the site in general, among gravediggers apparently went so far as to reinsert, or to in other ways reincorporate, teeth that had fallen from their alveoli during handling. This report describes and interprets a new find, i.e., an anatomically accurate, life-size shell carving of a human incisor, that provides additional insight into the apparent importance of teeth to these desert people. Dental Anthropology 2004;17(1): 28-31.

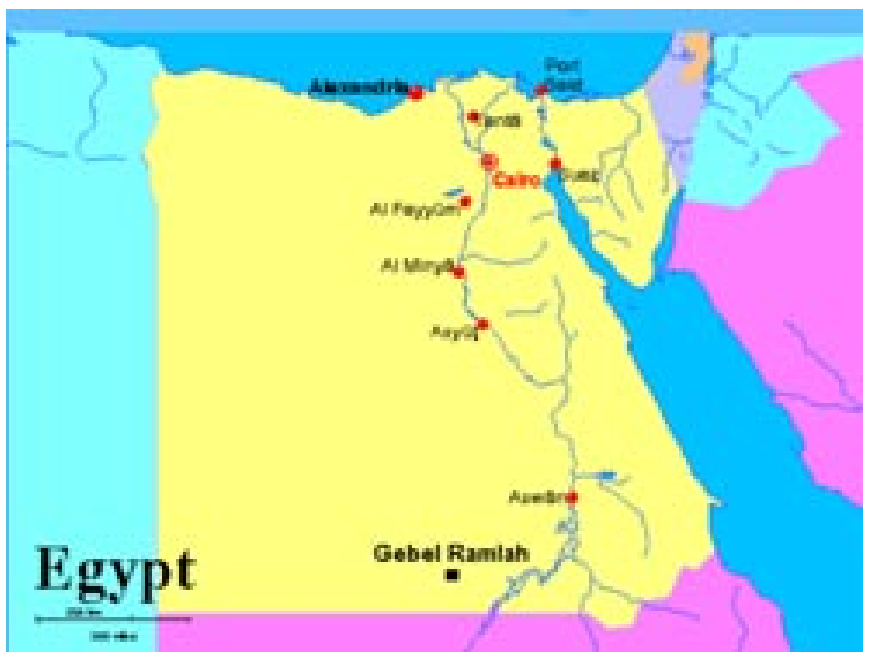

Fig. 1. Location of Gebel Ramlah.

others (paleodemography, geologic information, etc.), are presented in Irish et al. (2003), Schild et al. (2002), and Kobusiewicz et al. (n.d.).

In 2003 the remaining burial concentrations were excavated. Both also date to the Final Neolithic. During the course of fieldwork, two finds were made that provide additional evidence concerning the apparent importance of teeth to the local inhabitants. One, again, involves deliberate dental repositioning during the mortuary process; it is detailed elsewhere (Irish et

*Address for correspondence: Joel D. Irish, Department of Anthropology, P.O. Box 757720, University of Alaska Fairbanks, Fairbanks, AK 99775-7720, U.S.A.

E-Mail: ffjdi@uaf.edu 


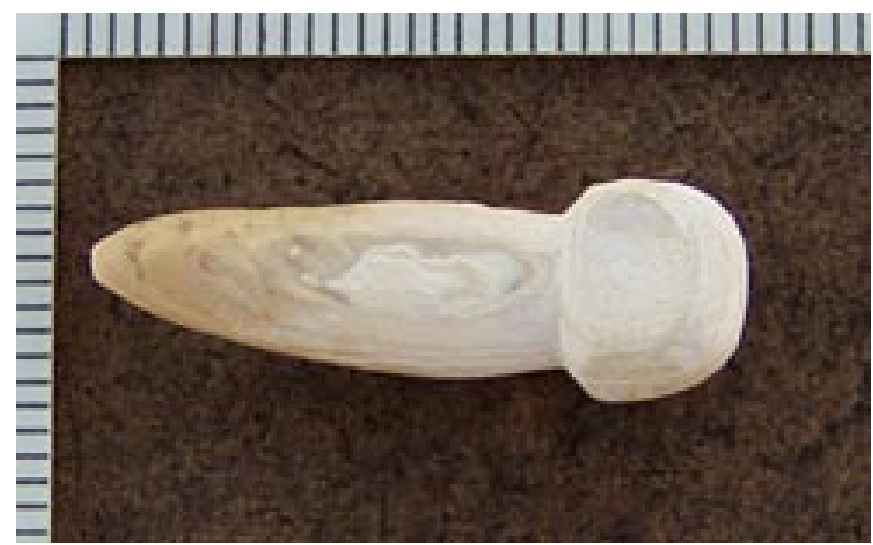

Fig. 2. Lingual view of the carved shell tooth. Note indication of slight shoveling. Tick marks on the margins are 1 millimeter intervals.

al., n.d.). The other find, a shell fragment carved in the shape of a human tooth, is discussed here.

\section{THE CARVED TOOTH}

During archaeological reconnaissance of the Gebel Ramlah cemetery, the second author discovered a small, purposefully-carved object located approximately equidistant to the three burial concentrations. This object was recovered from the desert surface, so its original, exact provenience is unknown. However, because it was found near bone fragments and artifacts analogous to those within the recovered Final Neolithic burials, it is likely contemporary. Because of deflation, only those skeletons and grave goods that had been deeply buried remain in situ. A Neolithic date is also inferred because no remains affiliated with other cultural/temporal periods were observed at the cemetery.

The material from which the object was carved is shell. Although the species is unknown, it appears to have been a large mollusk - which is more indicative of a salt-, rather than freshwater origin. Thus, it may

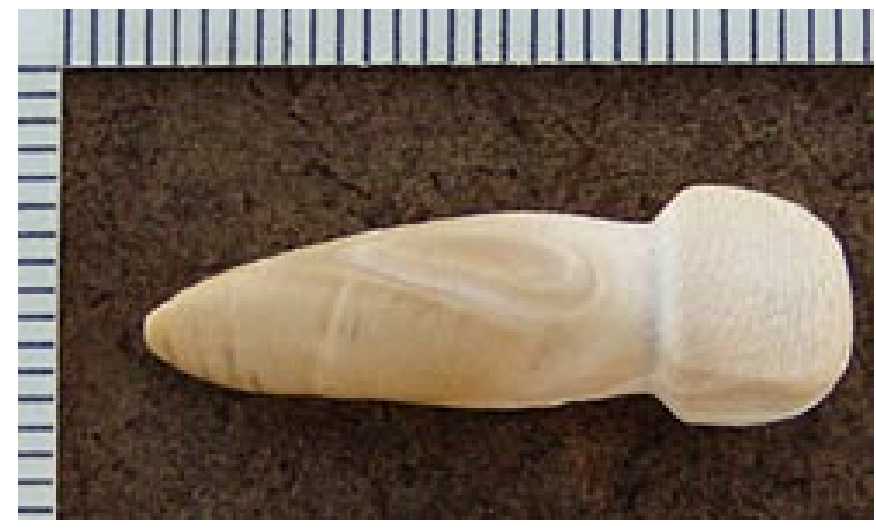

Fig. 4. Labial view of the carved shell tooth. Tick marks on the margins are 1 millimeter intervals.

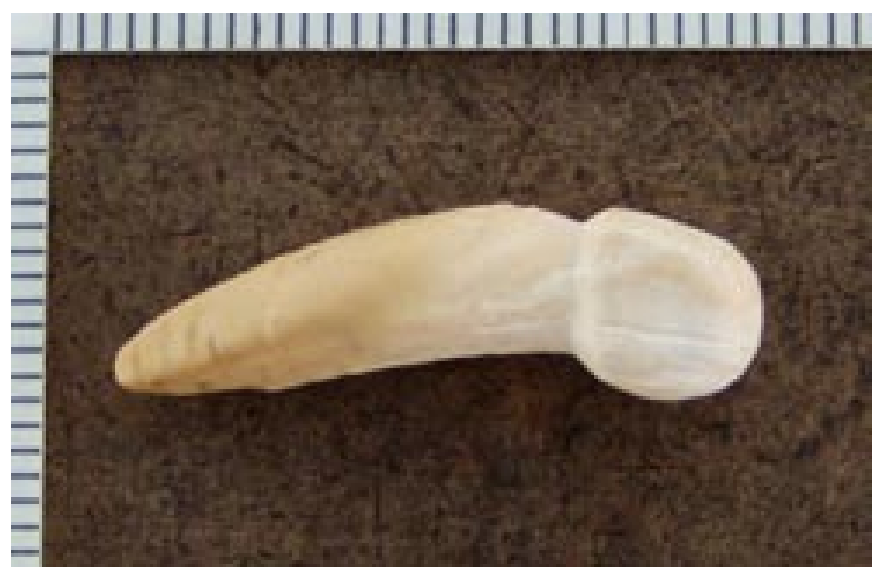

Fig. 3. Mesial view of the carved shell tooth. Tick marks on the margins are 1 millimeter intervals.

be derived from the Red Sea; several identifiable shells from this water source were found within intact burials. Although other interpretations are possible (e.g., miniphallus?), it is almost certainly a life size rendition of a human maxillary incisor-specifically, a left central or perhaps lateral tooth. As evident in Figures 2 through 5 , the object's "morphology" closely corresponds to this determination. Everything from an incisor's large, pointed single root, to its constricted neck and straight incisal edge are skillfully rendered. Moreover, an indication of slight shoveling is detectable on what would be the object's lingual surface (Fig. 2). The lingual and labial (Fig. 4) aspects of the "crown" are similar in appearance to that of a left central incisor. However, the occlusal view (Fig. 5) is suggestive of a more asymmetrical left lateral incisor. Indeed, mesiodistal and buccolingual measurements (using the method of Moorrees, 1957) taken of the object's "crown," 7.7 and

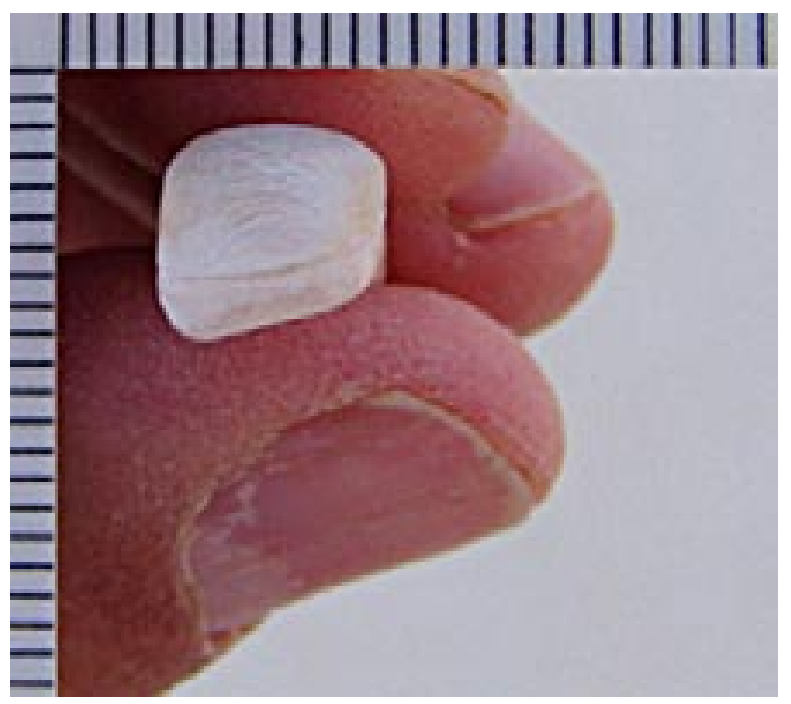

Fig. 5. Occlusal view of the carved shell tooth. Tick marks on the margins are 1 millimeter intervals. 
$7.1 \mathrm{~mm}$ respectively, are close to that of mean diameters obtained from actual Gebel Ramlah male lateral incisors. These and other values (i.e., males, females, sexes pooled) for both maxillary central and lateral incisors are presented in Table 1 for comparison. Although not measured in the actual Gebel Ramlah teeth, the object's "crown" height $(7.2 \mathrm{~mm})$, "root" length $(15.3 \mathrm{~mm})$, and overall length $(22.5 \mathrm{~mm})$ are well within the normal range of variation for human maxillary incisors (e.g., Lavelle, 1968; personal observations by first author).

Because the carved tooth was not recovered in situ, its intended purpose is difficult to ascertain. Still, it is plausible that it might fit into one of two broad functional categories, i.e., decorative object or surrogate human incisor.

With reference to the first category, the tooth may have been an objet d'art, and/or was meant to be worn as jewelry. Shell (as well as ivory, bone, and stone) bracelets, rings, and bead necklaces were found within the intact burials. Yet, if it was part of a necklace, or in some other way intended to be worn, it would probably exhibit a hole to facilitate attachment-in the same manner that all of the aforementioned beads were delicately drilled. Another possibility is that the tooth was an amulet. As described by Bonner (1950) and reviewed by Becker (1999), such amulets were often found in more recent Egyptian burials. It is reported that these "votive objects and other types of charms ... were commonly placed [fittingly] in the mouths of Egyptian mummies" (per Jonckheere, 1958, as quoted in Becker, 1999:22). The carved tooth may represent a Neolithic example of this later, more widespread practice.

Because the tooth is, more or less, anatomically accurate in size and appearance, there may be another possibility regarding its function. Perhaps it was intended as a replacement for an actual human incisor. The Egyptians are documented to have practiced basic dentistry by at least 2900 BC (Perine, 1883, as quoted in Becker, 1999; Ring, 1985). More to the point, there are reports that they may have employed false teeth or prostheses (Puech, 1995; Ring, 1985); later Mediterranean area populations (e.g., Phoenicians, Etruscans) certainly did (Ring, 1985; Becker, 1994a, 1996; Teschler-Nicola et al., 1998). However, as demonstrated by Becker (1999: 20) (but see Puech, 1995 for another view), there is "no evidence that dental prostheses were made before 630 $\mathrm{BC}$ or that they were fashioned in Egypt or even present there until after 400 BC." To further dissuade any idea that the tooth was a prosthesis, it has been shown that all examples of ancient false teeth are limited to the crowns only. In order for the present shell tooth (which includes the root) to be employed, it would have had to be implanted into an alveolus. Dental implantation is a relatively recent invention, having first been clinically introduced in 1918 (Ring, 1985); to date, no irrefutable ancient examples have been documented (see Becker, 1994b, 1999).

Although it seems unlikely that the shell incisor served in a functional masticatory capacity, it may still have been intended to take the place of an actual human tooth. That is, perhaps it was inserted into the alveolus of an incisor lost postmortem. As noted above and elsewhere (Irish et al., 2003, n.d.), extreme care was taken by the Neolithic inhabitants during reburial of disturbed remains. Such care included collection and, in some cases, reinsertion of loose teeth. Perhaps the shell tooth was fashioned to replace the misplaced incisor of an individual disturbed by a later burial. After all, it does seem that the intent at Gebel Ramlah was to "... return these [disturbed] individuals to the soil in as complete of a state as possible" (Irish et al., 2003: 281). In what may be deemed analogous treatment, two sets of more recent, Old Kingdom (ca. 2500 BC) remains from Giza and El Qatta in Lower Egypt, exhibit apparent post-mortem insertion of several teeth during the mummification process; however, in these cases actual human teeth, bound together with gold wire, were employed (see Junker, 1914; Harris et al., 1975; Ring, 1985; Puech, 1995). As stated by Ring (1985:36), in accordance with Junker's (1914) own observations (and similar to that noted above), this treatment was

TABLE 1. Measurements of carved shell tooth compared to mean crown diameters of maxillary incisors in the Gebel Ramlah (GR) skeletal sample.

\begin{tabular}{ccc}
\hline Specimen or Sample & $\begin{array}{c}\text { Mesiodistal } \\
\text { Dimension }\end{array}$ & $\begin{array}{c}\text { Buccolingual } \\
\text { Dimension }\end{array}$ \\
\hline Shell Tooth & $7.7 \mathrm{~mm}$ & $7.1 \mathrm{~mm}$ \\
GR Maxillary Central Incisors & \\
Sexes Pooled ${ }^{1}$ & $\begin{array}{l}8.91 \\
(\mathrm{n}=22)\end{array}$ & $\begin{array}{l}7.36 \\
(\mathrm{n}=23)\end{array}$ \\
Males Only & $\begin{array}{l}9.13 \\
(\mathrm{n}=6)\end{array}$ & $\begin{array}{l}7.80 \\
(\mathrm{n}=6)\end{array}$ \\
Females Only & $\begin{array}{l}8.78 \\
(\mathrm{n}=12)\end{array}$ & $\begin{array}{l}7.20 \\
(\mathrm{n}=13)\end{array}$ \\
GR Maxillary Lateral Incisors & \\
Sexes Pooled & 6.97 & 6.74 \\
& $(\mathrm{n}=20)$ & $(\mathrm{n}=21)$ \\
Males Only & 7.60 & 7.06 \\
& $(\mathrm{n}=6)$ & $(\mathrm{n}=5)$ \\
Females Only & 6.72 & 6.70 \\
$(\mathrm{n}=11)$ & $(\mathrm{n}=12)$ \\
\hline
\end{tabular}

${ }^{1}$ Gebel Ramlah is coded GR. Sexes pooled samples include individuals of indeterminate sex. 
apparently done to "... inter a corpse in as complete a state as possible, for they [the Egyptians] firmly believed that the body must be kept intact to house the soul in the afterworld." The only other documented pre-modern example that may serve as a corollary for the Neolithic tooth's postmortem functional interpretation comes from Honduras. An AD 600 Mayan mandible from the Ulúa Valley contains three artificial teeth, also carved from shell, that were inserted into the incisor alveoli (Ring, 1985).

\section{CONCLUSION}

The actual purpose of the carved shell tooth is, of course, conjectural and will likely never be conclusively determined. Yet, whether decorative or functional, the fact that the time was taken to carve such an anatomically accurate rendering suggests that teeth may have played a relatively important role in everyday life, or death. Moreover, although small, it and other better documented finds (Irish et al., 2003, n.d.) continue to provide insight into Egyptian Neolithic mortuary practices, and help add a measure of humanness to these desert folk beyond that ordinarily encountered in an archaeological setting.

\section{ACKNOWLEDGMENTS}

Our gratitude is extended to the Geological Survey of Egypt and the Supreme Council of Antiquities. We also thank Dr. Fred Wendorf, Southern Methodist University, and Ms. Heba Baset, Antiquities Inspector, Abu Simbel Office, Egypt. Fieldwork was financed by the State Committee of Scientific Research through the Institute of Archaeology and Ethnology, Polish Academy of Sciences. A portion of the travel funding for the first author was made possible through a National Science Foundation grant (BCS-0119754) awarded to Dr. Jerome Rose, University of Arkansas.

\section{LITERATURE CITED}

Becker MJ. 1994a. Etruscan gold dental appliances: Origins and functions as indicated by an example form Orvieto in the Danish National Museum. Dental Anthropology Newsletter 8:2-8.

Becker MJ. 1994b. Spurious "examples" of ancient dental implants or appliances. Dental Anthropology Newsletter 9:5-10.

Becker MJ. 1996. An unusual Etruscan gold dental appliance from Poggio Gaiella, Italy. Dental Anthropology Newsletter 10:10-16.

Becker MJ. 1999. Ancient "dental implants": A recently proposed example from France evaluated with other spurious examples. Int J Oral Maxillofacial Implants 14:19-29.
Bonner C. 1950. Studies in magical amulets, chiefly Graeco-Egyptian. Ann Arbor: University of Michigan Press.

Harris JE, Iskander Z, Farid S. 1975. Restorative dentistry in ancient Egypt: an archaeological fact. J Michigan Dent Assoc 57:401-404.

Irish JD, Kobusiewicz M, Schild R, Wendorf F. 2003. Neolithic tooth replacement in two secondary burials from Southern Egypt. J Archaeol Sci 30:281285.

Irish JD, Kobusiewicz M, Kabaciski J, Schild R. n.d. Two additional Egyptian Neolithic burials exhibiting unusual mortuary treatment of teeth. J Int Osteoarch (Under Review).

Junker H. 1914. Expedition der Weiner Akademie 1914 auf dem Friedhof von Gizeh. Vorbericht.

Kobusiewicz M, Kabaciski J, Schild R, Irish J, Wendorf F. n.d. A Late Neolithic Cemetery at Gebel Ramlah Playa. Archaeology (In Press).

Lavelle CLB. 1968. Anglo-Saxon and modern British teeth. J Dent Res 47:811-815.

Moorrees CFA. 1957. The Aleut dentition: A correlative study of dental characteristics in an Eskimoid people. Cambridge: Harvard University Press.

Puech PF. 1995. Dentistry in ancient Egypt: Junker's teeth. Dental Anthropology Newsletter 10:5-7.

Ring ME. 1985. Dentistry: an illustrated history. New York: Harry N. Abrams, Inc., Publishers.

Schild R, Kobusiewicz M, Wendorf F, Irish JD,

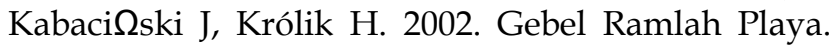
In: Lenssen-Erz T, Tegtmeier U, Kröpelin S, editors. Tides of the desert: contributions to the archaeology and environmental history of Africa in honour of Rudolph Kuper. 14 Africa Praehistorica, monographs on African archaeology and environment. Cologne: Heinrich-Barth Institut, University of Cologne, p 117123.

Teschler-Nicola M, Kneissel M, Brandstätter, Prossinger H. 1998. A recently discovered Etruscan dental bridgework. In: Alt KW, Rösing FW, Teschler-Nicola M, editors. Dental anthropology: fundamentals, limits, and prospects. New York: Springer, p 57-68.

Wendorf F, Schild R. 1999. Introduction. In: Nelson K, editor. Archaeology manual: Archaeological techniques in Saharan archaeology. Prepared for the Institute of International Education, Subcontract No. 99-048, p 1-14.

Wendorf F, Schild R. 2001. Introduction. In: Wendorf F, Schild R, editors. Holocene settlements in the Egyptian Sahara. Vol. 1, The archaeology of Nabta Playa. New York: Kluwer Academic/Plenum Press, p 1-10.

Wendorf F, Schild R (assemblers), Close AE, editor. 1984. Cattle keepers of the Eastern Sahara: The Neolithic of Bir Kiseiba. Dallas: Southern Methodist University. 